\title{
AGRONOMIC CHARACTERISTICS OF LYPOXYGENASE-FREE SOYBEAN INTRODUCED IN LOW LATITUDES OF THE STATE OF TOCANTINS
}

\author{
SANTOS, Elonha Rodrigues ${ }^{1}$ \\ SPEHAR, Carlos Roberto ${ }^{1}$ \\ CAPONE, Aristoteles ${ }^{2}$ \\ SANTOS, Adão Felipe ${ }^{3}$
}

SUMMARY: This study aimed at evaluating physiological and agronomic components of food type soybean introduced in the State of Tocantins, as compared to common type locally adapted cultivars. The experiment was conducted at the Federal University of Tocantins, located at $11^{\circ} 43^{\prime} \mathrm{S}$ and $49^{\circ} 04^{\prime} \mathrm{W}$. The experimental design was randomized complete block with four cultivars and four repetitions of food type BRSMG790A and BRS 257, and common type A7002 and M 8585. Evaluations were made on plant height (PH), number of days to flowering (NDF), number of days to maturity (NDM), number of days of the reproductive period (NDPR), number of pods per plant (NPP), dry matter yield (DMY), grain yield (GY), leaf area (LA) and growth rates: leaf area index (LAI), leaf area ratio (LAR), net assimilation rate (NAR), absolute growth rate (AGR) and relative growth rate (RGR). The BRSMG 790A and BRS 257 had lower PH, LA, LAI, LAR, NAR, AGR and RGR, reflected by NDF and maturity, reducing NPP, DMY and GY. These lypoxigenase free cultivars are not adapted to soybean commercial production at low the latitudes of Tocantins but can be employed in hybridization with long-juvenile, locally adapted cultivars, being a source of genetic diversity in breeding programs.

Keywords: Leaf area index. Net assimilation rate. Relative growth rate. Lleaf area ratio. Dry matter.

RESUMO: Este trabalho objetivou avaliar os componentes fisiológicos e agronômicos de soja tipo alimento, introduzida no Estado do Tocantins, em comparação com soja tipo comum selecionada para as baixas latitudes. $\mathrm{O}$ experimento foi conduzido na Universidade Federal do Tocantins, localizado a11 ${ }^{\circ} 43^{\prime} \mathrm{S}$ e $49^{\circ} 04^{\prime} \mathrm{W}$. O desenho experimental foi de blocos ao acaso com quarto cultivares e quarto repetições. Os tratamentos foram BRSMG790A e BRS 257, do tipo alimento; A7002 e M 8585 do tipo comum de grão. Avaliaram-se: altura de plantas (AP), número de dias para o florescimento (NDF), número de dias para a maturação (NDM), número de dias do período reprodutivo (NDPR), número de vagens por planta (NPP), produção de matéria seca (PMS), produção de grãos (PG), área foliar (AF) e taxas de crescimento: índice de área foliar (IAF), taxa de área foliar (TAF), taxa de assimilação líquida (TAL), taxa absoluta de crescimento (TAC) e taxa relativa de crescimento (TRC). Os genótipos BRSMG 790A e BRS 257, apresentaram valores mais baixos de AP, AF, IAF, TCA, TAL, TCA e TCR, refletida pelo NDF e maturação, reduzindo o NVP, MS e RG. Estes cultivares livres de lipoxigenase mostraram-se não adaptados à produção comercial de soja no Estado do Tocantins, mas podem ser empregados em hibridações com soja adaptada localmente, possuindo período juvenil longo, constituindo-se em fonte de variabilidade genética em programas de melhoramento de soja às baixas latitudes.

Palavras-chave: Índice de área foliar. Taxa de assimilação líquida. Taxa de crescimento relativo. Razão de área foliar. Matéria seca.

\section{INTRODUCTION}

Soybeans (Glycine max L.) has been introduced and selected to commercial production in major producing countries, the United States of America and Brazil, where it is mostly directed to oil and animal

\footnotetext{
${ }^{1}$ Engenheira Agrônoma; Mestre em Produção Vegetal - Universidade de Brasilia

${ }^{2}$ Universidade Federal do Tocantins

${ }^{3}$ Unesp
} 
feed. However, in Asian countries as China, Korea and Japan it has been cultivated since millennia as important source of proteins and other compounds as carbohydrates, fibber, minerals, vitamin A, E, B1and B2 to humans. Soybean possesses functional properties and contributes to human health, being protein rich, source of isoflavones (SILVA et al., 2012) and alternative to lactose intolerant patients.

Soybean byproducts have gained space in the market for intrinsic health conditioning properties. However, it is estimated that only $6 \%$ of the soybean produced in Brazil is destined to food products. Even though the benefits of soybean derived products have been demonstrated, many potential consumers avoid using them in diet, mainly due to the presence of undesirable odor and flavor by lypoxygenase enzymes in common type soybean (SILVA et al., 2009).

The sensorial difference make common soybean undesirable in food preparations such as tofu and other derived food. The breeding programs have developed food type cultivars as lypoxigenase free BRS 257 and BRSMG 790A, of better flavor than common type soybean (SILVA et al., 2012). Food type cultivars have been selected to a narrow latitude zone, lacking alleles conditioning long juvenile trait that extend vegetative period and present in tropical adapted genotypes (SPEHAR et al., 2014).

Growth analysis is based on the fact that about $90 \%$ of accumulated dry matter by the plants results from photosynthetic activity alone. It allowed assessing the final plant growth and relative contribution of the plant parts in soybean development under different cropping systems (YUSUF et al., 1999). In spite of its complexity, growth pattern has shown rather precise to evaluate and understand physiological processes, quantifying plant response to environmental variations (MEHMET SINCIK et al., 2011). Moreover, it has been useful in crop breeding for higher photosynthetic efficiency and yield (MORRISON et al., 1999).

Genotype introduction has been an approach to initiate breeding and adapt a crop into new environment, while growth analysis allows estimating the causes of variations in plant development. It has been essential to understand functional and structural differences among genotypes of same species aiming at selection for yield stability (SPEHAR et al., 2014).

Applications of growth analysis have been reported to define the phases of plant development of several crops as castor bean (SANTOS et al., 2011c), cowpea (SANTOS et al., 2011a; FREITAS et al., 2014), tomato (MARTINAZZO et al., 2015), rice (ALVAREZ et al., 2015) and soybean (BULEGON et al., 2016; OLIVEIRA et al., 2013; CRUZ et al., 2010 e YUSUF et al., 1999).

The potential to grow soybean in low latitudes of Brazil has been realized by selecting cultivars with extended vegetative phase, incorporating alleles for long juvenile period (SPEHAR et al., 2014). These alleles induce the plant to grow and yield at levels comparable to the ones obtained in temperate regions or the world. Producing areas in the State of Tocantins are located at latitudes between $5-13^{\circ} \mathrm{S}$ and low altitude where common type soybean has been adapted competitively. However, cultivation of lypoxigenase free soybean in this region has not yet been realized, justifying studies to understand genotypic growth and reproduction phases.

This study aimed at evaluating food-type soybean cultivars introduced in the State of Tocantins and common type locally selected on the basis of growth analysis and agronomic performance. It is expected the results could be useful in breeding programs to acquire yield competitive lypoxigenase-free cultivars to low latitude, low altitude tropical areas.

\section{MATERIAL AND METHODS}

The experiment was conducted in the Federal University of Tocantins, Campus of Gurupi, Tocantins located at $11^{\circ} 43^{\prime} \mathrm{S}, 49^{\circ} 04^{\prime} \mathrm{W}$ and altitude of $280 \mathrm{~m}$, on red yellow oxisol or Ferralsol in 
FAO's soil classification (IUSS Working Group WRB, 2015). The soil was previously amended with lime and the analysis presented the following chemical and physical composition: $\mathrm{pH}=5.6 ; \mathrm{Al}^{+3}+\mathrm{H}^{+1}=2,6$ $\mathrm{cmol}_{\mathrm{c}} \mathrm{dm}^{-3} ; \mathrm{Ca}+\mathrm{Mg}=2,8 \mathrm{cmol}_{\mathrm{c}} \mathrm{dm}^{-3} ; \mathrm{K}=72 \mathrm{mg} \mathrm{dm}{ }^{-3} ; \mathrm{P}=3,7 \mathrm{mg} \mathrm{dm}^{-3}$; base saturation $(\mathrm{BS})=53.5 \%$; cation exchange capacity $(\mathrm{CEC})=5.6 \mathrm{cmol}_{\mathrm{c}} \mathrm{dm}^{-3}$; organic matter: $2.2 \mathrm{dag} \mathrm{kg}^{-1}$; sand $=71 \mathrm{dag} \mathrm{kg}^{-1}$; silt $=$ 5.0 dag $\mathrm{kg}^{-1}$; clay $=24,0 \mathrm{dag} \mathrm{kg}^{-1}$.

The climate was classified as Aw, wet with moderate water deficit (KOTTEK et al., 2006). During the plant growth the climate data were collected in the Meteorological Station at Gurupi Campus (Figure 1).

Figure 1. Maximum and minimum temperatures $\left({ }^{\circ} \mathrm{C}\right)$, daily rainfall pluvial $(\mathrm{mm})$ and mean air relative humidity (\%), between 29 May and 25 September 2010, Gurupi, Tocantins, Brazil.

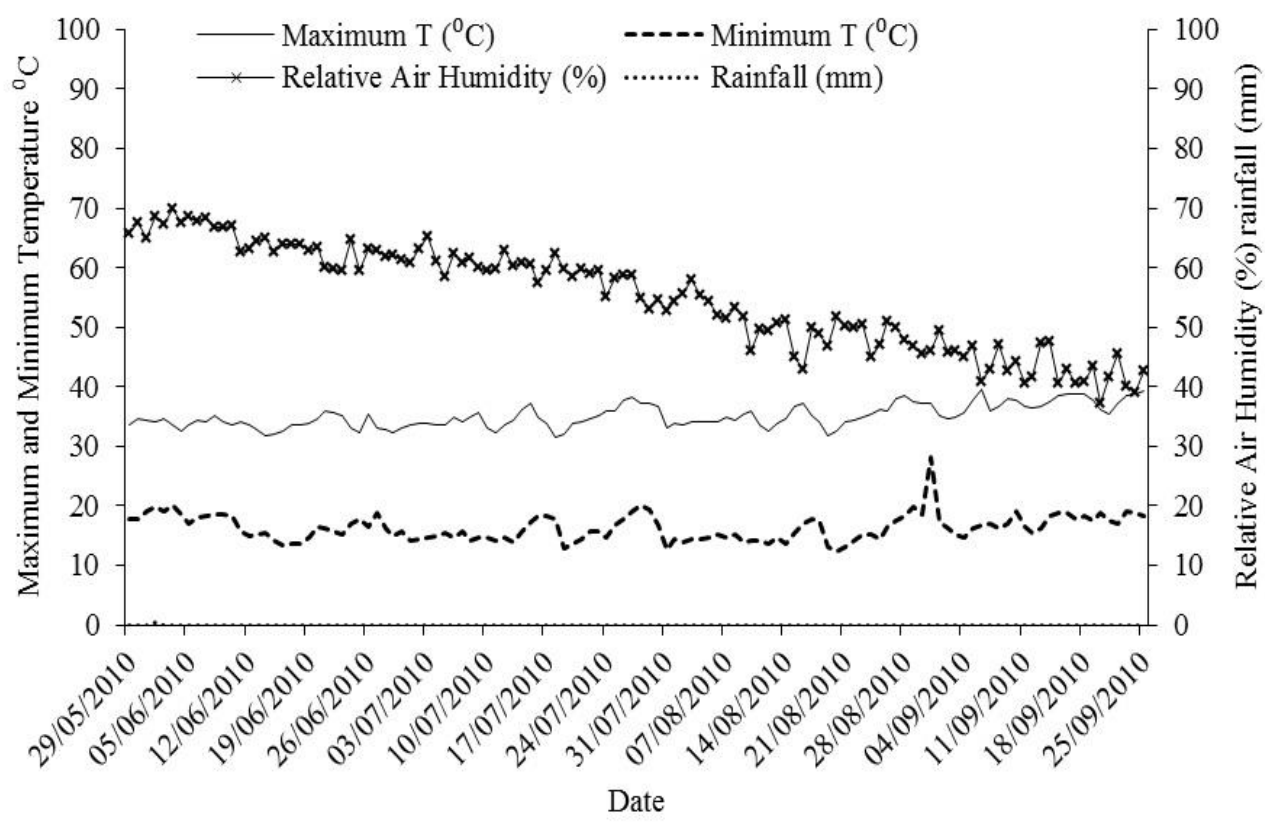

Source: Elaborated by the authors from the climatic data of the Meteorological Station at Gurupi-TO, Brazil.

The experiment was sown in no-till system, on 29 May 2010. Fertilization, based on soil analysis and to supply plant requirements in phosphorus (P) and potassium (K), consisted of $60 \mathrm{~kg} \mathrm{ha}^{-1} \mathrm{P}_{2} \mathrm{O}_{5}, 60 \mathrm{~kg}$ $\mathrm{ha}^{-1} \mathrm{~K}_{2} \mathrm{O}$, formulated 00-16-16 NPK. Nitrogen (N) was supplied by association of plants and the bacterium strains of Bradyrhizobium japonicum, from inoculated seeds before sowing.

The experimental design was complete randomized blocs with four treatments and four repetitions. The treatments consisted of two food type cultivars: BRSMG 790A and BRS 257; and two common type cultivars: A7002 e M 8585. These cultivars have been recommended to a range of latitudes, belonging to different maturity groups and obtained by public and private breeding institutions (Table 1). 
Table 1. Cultivars utilized in the experiment with respective recommended states of cultivation, maturity group and Institution of origin.

\begin{tabular}{llcl}
\hline Cultivar & Recommended State & Maturity Group* & Institution \\
\hline BRSMG 790A & MG, GO, DF e SP & 7.9 & Epamig-MG \\
BRS 257 & RS, PR, SP & 6.4 & Embrapa soja \\
A 7002 & MT, MG, GO, DF, TO & 8.2 & Nidera \\
M 8585 & MT, MG, GO, DF, TO & 8.5 & Monsanto
\end{tabular}

*Maturity Group classification ranging from 4.5 (early) to 9 (late), covering Southern Brazil to Equatorial zone. Source: Tecnologias de Produção de Soja - Região Central do Brasil 2013. https://www.embrapa.br/busca-depublicacoes/-/publicacao/975595/tecnologias-de-producao-de-soja---regiao-central-do-brasil-2014.

Each plot was made by five $6.00 \mathrm{~m}$ long rows, spaced by $0.45 \mathrm{~m}$, and $0.08 \mathrm{~m}$ between plants in the row, corresponding to a population density of $27810^{3}$ plants $^{-1} \mathrm{a}^{-1}$. The measurements for growth analysis were taken on the second row, which was subdivided into 10 subplots, for periodical sampling. The $4^{\text {th }}$ row was harvested at maturity to biomass and grain yield evaluations. The experiment was kept weed free by hand hoeing and irrigated before VC until R8 (FEHR et al, 1971) with sprinklers using a net wet line of $6 \mathrm{~mm}$, every three days, maintaining the water tension in soil at $65-70 \%$ field capacity.

Five plants were collected in each plot at 15, 25, 35, 45, 55, 65, 75, 85, 95 and 105 days after emergence (DAE) and utilized in growth analysis. The measurements were as follows: a) plant height $(\mathrm{PH})$, from the plant base to the apex containing unopened leaves using a measuring tape to nearest mm; b) total dry matter yield (TDMY), by dividing the plants into the respective parts - leaves, stem, flowers and pods and drying up in forced ventilation muffle at $70{ }^{\circ} \mathrm{C}$ to constant weight and weighing in precision balance; c) leaf area (LA), determined from scanning the leaf limbs using Lexmark X75, Lexmark, Incorporated, Lexington, KY, USA, using the shade to calculate the area by image interpretation (PAPA, 2009); d) leaf area index (LAI): determined by the relation between mean leaf area of plants and the land surface of projected canopy in $\mathrm{m}^{2} \mathrm{~m}^{-2}$; e) leaf area ratio (LAR): defined as the ratio between LAI and TDMY, in $\mathrm{m}^{2} \mathrm{~g}^{-1}$; $\mathrm{f}$ ) net assimilation rate (NAR): determined by the ratio between crop growth ratio (CGR) and LAI, in $\mathrm{g} \mathrm{m}^{-2} \mathrm{dia}^{-1} ; \mathrm{g}$ ) absolute growth ratio (AGR); h) relative growth ratio (RGR): expressed in $\mathrm{g} \mathrm{g}^{-1} \mathrm{dia}^{-1}$ and calculated by dividing CGR to TDMY. The crop growth measurements and their analysis were adapted from existing methodology (HOFFMANN; POORTER, 2002; PRICE; MUNNS, 2010).

In growth analysis, best fit curves for linear and quadratic polynomial models were obtained using the means for each collecting time. The best fit to the data was based on the highest determination coefficient $\left(\mathrm{R}^{2}\right)$, allowing definition of plant growth pattern (PRICE; MUNNS, 2010).

The agronomic characteristics were evaluated as follows: a) number of days to first flower (NDF) - corresponding to the period between emergence and $50 \%$ of plants with at least one flower; $b$ ) number of days for maturation (NDM) - period between emergence and $95 \%$ of plants presenting ripe pods; c) number of days to reproductive period (NDRP) - period between NDF and NDM; d) number of pods per plant (NPP) - mean pod number of five plants; grain yield (GY) - obtained by harvesting the plants on the $4^{\text {th }}$ row, threshing, cleaning, drying, weighing, and converting to $\mathrm{kg} \mathrm{ha}^{-1}$ at $13 \%$ humidity. Data were subject to analysis of variance and means separated by Tukey test $(\mathrm{p} \leq 0.05)$, using the SISVAR statistical program. 


\section{RESULTS AND DISCUSSION}

Plant height had a significant quadratic response, with $\mathrm{R}^{2}$ of 0.97 and 0.98 (Table 2 and Figure 2A). Irrespective of cultivar, the initial growth was slow until 25 days after emergence (DAE). After this point, cultivars A7002 e M 8585 had outstanding growth, relative to food type BRSMG 790A and BRS 257, until 65 DAE. The plant height of BRS 257 stabilized at 45 DAE while for BRSMG790A it happened at 55 days after emergence. These cultivars had expressive difference in plant height varying from $82 \mathrm{~cm}$ of common type to respective 48.6 and $36.5 \mathrm{~cm}$ to BRSMG 790A and BRS 257 food type. The quadratic response for plant growth was also observed in soybeans grown in high northern latitudes (PEDERSEN; LAUER, 2004)

Table 2. Adjusted equations for plant height (PH), total dry matter yield (TDMY), leaf area (LA), leaf area index (LAI), leaf area ratio (LAR), net assimilation rate (NAR), absolute growth rate (AGR) and relative growth rate (RGR) of food type BRSMG 790A and BRS 257 and A7002 e M 8585 common type soybean grown in Gurupi, Tocantins, Brazil.

\begin{tabular}{|c|c|c|c|c|}
\hline Cultivar & $\mathrm{PH}(\mathrm{cm})$ & $\mathrm{R}^{2}$ & TDMY (g plant $\left.{ }^{-1}\right)$ & $\mathrm{R}^{2}$ \\
\hline BRSMG790A & $y=-0,008 x^{2}+1,372 x-9,957$ & $0,97^{28}$ & $y=4,4473 x-7,6086$ & $0,93^{* \pi}$ \\
\hline BRS257 & $y=-0,0075 x^{2}+1,072 x-1,482$ & $0,98^{* *}$ & $y=3,5128 x-5,3048$ & $0,97^{* *}$ \\
\hline A7002 & $y=-0,013 x^{2}+2,401 x-26,99$ & $0,98^{* x}$ & $y=4,2745 x-9,4902$ & $0,91^{* *}$ \\
\hline M8585 & $y=-0,0104 x^{2}+2,099 x-23,54$ & $0,98^{* x}$ & $Y=4,0444 x-8,364$ & $0,94^{* *}$ \\
\hline Cultivar & $\mathrm{LA}\left(\mathrm{cm}^{2}\right.$ plant $\left.^{-1}\right)$ & & LAF & \\
\hline BRSM790A & $y=-0,569 x^{2}+69,35 x-1069$ & $0,73^{*}$ & $y=-0,18 x^{2}+2,021 x-2,34$ & $0,73^{-}$ \\
\hline BRS257 & $y=-0,291 x^{2}+34,51 x-443,78$ & $0,86^{*}$ & $y=-0,092 x^{2}+1,003 x-0,88$ & $0,86^{*}$ \\
\hline A7002 & $y=-0,312 x^{2}+48,57 x-757,62$ & $0,82^{*}$ & $y=-0,099 x^{2}+1,443 x-1,66$ & $0,82^{*}$ \\
\hline M8585 & $y=-0,365 x^{2}+58,63 x-958,85$ & $0,83^{*}$ & $y=-0,116 x^{2}+1,745 x-2,14$ & $0,83^{*}$ \\
\hline Cultivar & $\operatorname{LAR}\left(\mathrm{cm}^{2} \mathrm{~g}^{-1}\right)$ & & $\operatorname{NAR}\left(\mathrm{g} \mathrm{cm}^{2} \mathrm{dia}^{-1}\right)$ & \\
\hline BRSM790A & $y=1,666 x^{2}-39,877 x+234,9$ & $0,99^{38}$ & $y=5 E-06 x^{2}-0,0002 x+0,0013$ & $0,96^{* 5}$ \\
\hline BRS257 & $Y=2,826 x^{2}-51,128 x+243$ & $0,99^{* *}$ & $y=-4 E-06 x^{2}-6 E-05 x+0,001$ & $0,99^{* *}$ \\
\hline A7002 & $y=0,326 x^{2}-24,66 x+229,63$ & $0,99^{* *}$ & $y=4 E-06 x^{2}-8 E-05 x+0,0007$ & $0,91^{* *}$ \\
\hline M8585 & $y=0,935 x^{2}-29,87 x+237,86$ & $0,98^{* *}$ & $y=5 E-06 x^{2}-8 E-05 x+0,0006$ & $0,95^{* *}$ \\
\hline Cultivar & AGR $\left(g^{1} \mathrm{dia}^{-1}\right)$ & & RGR ( $\left.\mathrm{g} \mathrm{g}^{1} \mathrm{dia}^{-1}\right)$ & \\
\hline BRSN & $y=0,0105 x^{2}+0,001 x+0,152$ & $0,98^{38}$ & $y=0,0039 x^{2}-0,0604 x+0,239$ & $0,96^{* 7}$ \\
\hline BRS257 & $y=-0,0013 x^{2}+0,085 x+0,013$ & $0,98^{* *}$ & $y=0,0035 x^{2}-0,0553 x+0,22$ & $0,97^{* *}$ \\
\hline A7002 & $y=0,01 x^{2}+0,0089 x+0,079$ & $0,99^{* *}$ & $y=0,0019 x^{2}-0,0316 x+0,150$ & $0,97^{* *}$ \\
\hline M8585 & $y=0,004 x^{2}+0,0511 x+0,010$ & $0,99^{* *}$ & $y=0,0024 x^{2}-0,0367 x+0,159$ & $0,97^{* *}$ \\
\hline
\end{tabular}

** And * significant at $\mathrm{P}<0.01$ and $\mathrm{P}<0.05$ respectively by $\mathrm{F}$-test

Source: Prepared by the authors of this article 
Figure 2. Plant height (A), dry matter (B), leaf area (C) and leaf area index (D) of food type BRSMG790A and BRS 257 and common type A7002 and M 8585 soybean cultivars in Gurupi, Tocantins, Brazil, 2010.
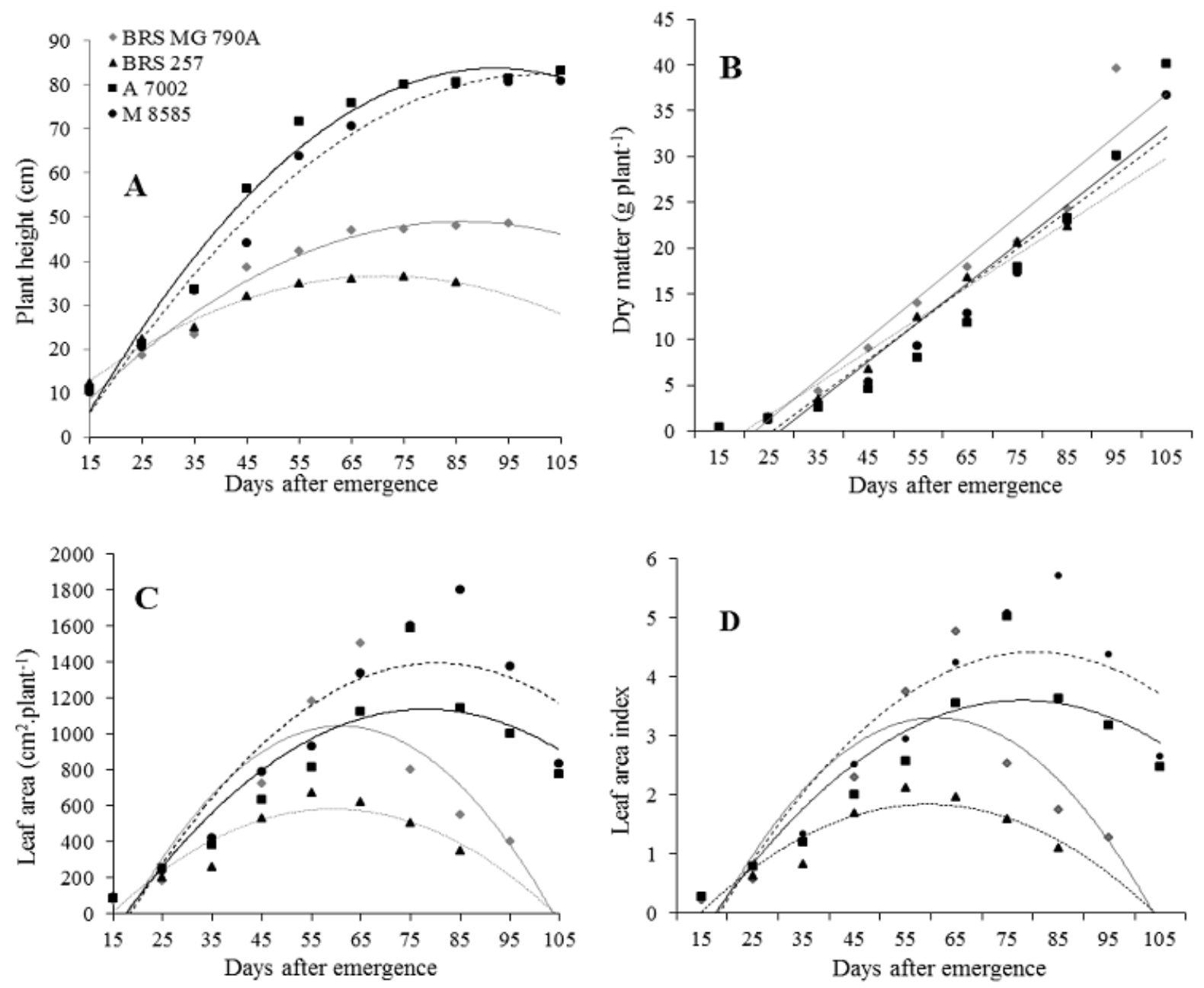

Source: Prepared by the authors of this article

Plant height is directly related to maturity groups, day length response and presence of long juvenile trait (SPEHAR et al., 2014). The food type cultivars had short plants, typical response to short day conditions prevailing in Tocantins, while plants of common type soybeans were tall to suit combine harvest. Genotypes devoid of juvenile alleles have started flowering at V3 in tropical regions, where plants grow under short day length (ALMEIDA et al., 1999). This early flowering resulted smaller plants with direct negative impact on biomass and grain yield (SPEHAR et al., 2014).

Dry matter (DM) yield by the plants, as a function of time, showed linear response by the cultivars (Figure 2B). However, the largest increments were observed for A7002, M8585 and BRSMG790A, while the least values were shown by BRS 257 (Figure 2B). From emergence until 35 DAE differences among cultivars were not significant. Between 45 e 75 DAE, food type cultivars had accumulated high dry matter. At 85 DAE, however there were differences among cultivars when BRS 257 had already passed physiological maturity, accumulating $22 \mathrm{~g}$ DM per plant. At 95 DAE the plant of BRSMG 790A reached maturity with $40 \mathrm{~g}$ dry matter. This was expected in view of the differences in maturity group. Early maturing BRS 257 yielded less than BRSMG 790A and the difference related to extending the plant cycle for additional ten days as demonstrated to common type soybeans (SPEHAR et al., 2014).

The cultivars A7002 and M 8585 behaved similarly in dry matter accumulation during the plant cycle (Figure 2B). Food type cultivars tended to accumulate biomass in a shorter period, coinciding with 
their selection and recommendation to Southern higher latitude areas. The earlier cycle (NDM) of food type BRS 257 and BRSMG790A than the common type A7002 and M 8585 had negative impact on number of pods per plant and grain yield (Table 3).

Table 3. Mean values for number of days to flowering (NDF), number of days to maturity (NDM), number of days of reproductive period (NDRP), number of pods per plant (NPP), and grain yield (GY) of food and common type soybean cultivars. Gurupi Tocantins, Brazil 2010.

\begin{tabular}{llllll}
\hline & \multicolumn{5}{c}{ Characteristics } \\
\cline { 2 - 6 } Cultivar & NDF & NDM & NDRP & NPP & GY $\left(\mathrm{Kg} \mathrm{ha}^{-1}\right)$ \\
\hline BRSMG 790A & $29 \mathrm{~b}$ & $96 \mathrm{c}$ & $67 \mathrm{~b}$ & $46 \mathrm{~b}$ & $1033 \mathrm{c}$ \\
BRS 257 & $24 \mathrm{c}$ & $78 \mathrm{~d}$ & $54 \mathrm{c}$ & $29 \mathrm{c}$ & $583 \mathrm{~d}$ \\
A7002 & $31 \mathrm{~b}$ & $108 \mathrm{~b}$ & $77 \mathrm{a}$ & $70 \mathrm{a}$ & $3696 \mathrm{a}$ \\
M 8585 & $39 \mathrm{a}$ & $126 \mathrm{a}$ & $81 \mathrm{a}$ & $77 \mathrm{a}$ & $3180 \mathrm{~b}$ \\
\hline Média & 31 & 101 & 70 & 55 & 1858
\end{tabular}

Means followed by same letter in the column are not statistically different (Tukey $\mathrm{p} \leq 0.05$ ).

Source: Prepared by the authors of this article

Linear response to dry matter accumulation was similar to the one obtained with gerbera (LUDWIG et al., 2010) while diverging results were obtained with rice (ALVAREZ et al., 2015) and soybean (OLIVEIRA et al., 2013). In the latter and former a sigmoid curve was the best fit to explain biomass production. However, at lower altitudes as Gurupi, where the experiment was conducted, higher temperatures contributed to accelerate plant cycle, when considered in degree days (SPEHAR et al., 2014), justifying the growth response presented here.

Leaf area (LA) and leaf area index (LAI) adjusted to quadratic model (Table 2) and showed similar trend (Figure 2C and 2D). The cultivars did not show significant differences in LA and LAI for the first 25 DAE. The maximum leaf area happened at 55 DAE for BRS 257 and at 65 DAE for BRSMG 790A. After this period, there was a reduction in LA and LAI, as in reproductive phase, photo assimilate drain intensified and was associated with mineral elements translocation, causing senescence of older leaves. This was noted when comparing common type to food type soybeans that presented the least values for both LA and LAI.

Leaf area index, measures the covering area represented by the leaves in the plant (PRICE e MUNNS, 2010). The lower index values of, food type, introduced cultivars were notorious when compared with common type locally selected cultivars. It must be said that BRS 257 had the lower LA with LAI of only 2.13 when compared to M 8585 and A7002 with LAI higher than 5.0 as would be expected (NGUY-ROBERTSON et al., 2010). The maximal LAI occurred at different times for the cultivars, justifying the varietal difference in maturity group conditioned by response to short day length. The maximum index values was observed at 55 DAE for BRS 257, at 65 DAE for BRSMG 790A, at 75 DAE for A7002 and at 85 DAE for M 8585 and these differences could also be associated to high temperature response (SPEHAR et al., 2014).

The decline in LAI after maximum leaf area verified to all cultivars could be ascribed to rapid photo assimilates drained to seed formation which increased dry matter at the time of biosynthesis of oil 
and protein (HEIFFIG et al., 2006). In addition, the rapid drain caused reduction in the effective leaf area, leading to senescence and loos of older leaves (CAMPOS et al., 2008).

In soybeans at $\mathrm{R}_{1}$ leaf area index has been reported to be 5.5 on high yielding commercial crop (NGUY-ROBERTSON et al., 2010). The lower LAI values by BRS 257 explain significant yield reduction reported here. Environmental factors as temperature and day length have direct effect on LAI, depending on latitude, altitude, sowing date and genotypic characteristics. This experiment was conducted under short day condition, causing anticipated flowering induction in cultivars that are early maturity and do not possess long juvenile alleles (SPEHAR et al., 2014). As a result of early flowering there was less plant growth, with reduced LA, implicating in lower number of pods and grains.

The leaf area ratio (LAR), corresponding to the ratio between the leaf area response to light interception, $\mathrm{CO}_{2}$ and dry matter, declines during plant growth, as a result of shading and consequent reduction of photo synthetically active area (PRICE e MUNNS, 2010). LAR showed a quadratic response with $\mathrm{R}^{2}$ varying between 0.98 and 0.99 (Table 2). It was maximal at $15 \mathrm{DAE}$ for all cultivars, with a continuous decline thereafter. (Figure 3A). The cultivars divided into two distinct groups, where food type had the lowest values at maturity were: 85 DAE to BRS 257, 95 DAE to BRSMG 790A and 105 DAE to A7002 e M8585.

Figure 3. A- Leaf area ratio (LAR), $B$ - net assimilation rate (NAR), absolute growth rate (AGR) - C and relative growth rate (RGR) - D of food type BRSMG790A and BRS 257, and common type A7002 and M 8585 soybean plants grown in Gurupi, TO.
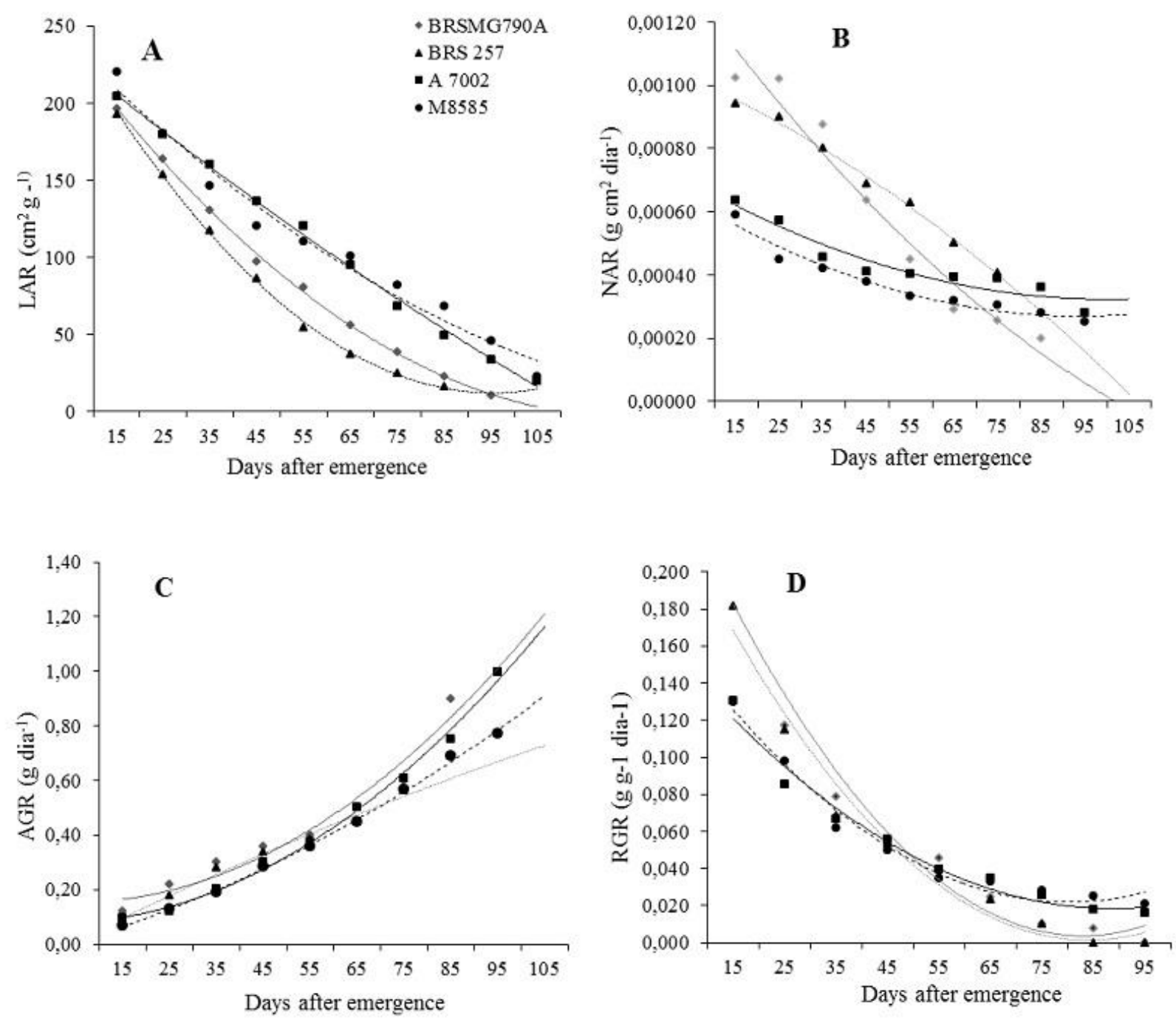

Source: Prepared by the authors of this article 
LAR has shown high value early in plant cycle as demonstrated here, as there is higher photo synthetic activity, by leaf expansion and light interception (LUDWIG et al., 2010). The values decline along the plant cycle due to shading of upper leaves to lower leaves. There is an inverse relation between leaf area and leaf area ratio, the plants fixing more carbon at lower LA. Similarly, the LAR reduced as tomato plants had grown and expanded leaf area (MARTINAZZO et al., 2015).

Net assimilation rate (NAR) represents the balance between the product of photosynthesis and the losses due to respiration, indicating plant efficiency in dry matter production. NAR was adjusted to quadratic model equation, where $\mathrm{R}^{2}$ varied between 0.91 to A7002 and 0.99 to BRS 257 (Table 2). NAR gradually decreased to all cultivars in the experiment (Figure 3B).

Food type cultivars BRSMG 790A and BRS 257 had higher NAR early in plant cycle than common type ones until 45 and 65 DAE respectively. The common type cultivars A7002 e M 8585 showed a steady increase in NAR throughout the evaluation period, with no significant difference between them. This performance probably occurred due to extended vegetative period, with lower initial indexes of photosynthesis but maintained during the longer plant cycle, indicating their adaptability to growth under low latitude high temperature.

The trend found here was divergent from the ones with cowpea and tomato plants (FREITAS et al., 2014; MARTINAZZO et al., 2015) where NAR gradually decreased throughout the plant cycle.

Absolute growth rate values (AGR) were adjusted to quadratic model equations for $\mathrm{R}^{2}$ between 0.98 and 0.99 (Table 2). The initial growth of plants was slow until 35DAE (Figure 3C). At 75 DAE all cultivars presented similar AGR but, thereafter, the common type cultivars had increasing values surpassing the food type cultivars.

The RGR had similar decreasing response as observed for LAR and AGR (Figure 3D). The RGR equations were significant for quadratic response with $\mathrm{R}^{2}$ of 0.96 and 0.97 (Table 2). The cultivars had two groupings: common type and food type soybeans. Within group there was no significant difference, corroborating difference in agronomic performance. From emergence to $35 \mathrm{DAE}$, food type soybeans had higher RGR and did not differ from common type soybeans at 45 and 55 DAE. The former kept increasing RGR and were significantly higher in later phase, similar to varietal differences in coffee plant growth (SOUZA et al., 2016). Increase and decline of RGR along the plant cycle are associated to fluctuations in the net assimilation rate (FREITAS, et al., 2014).

The mean values of NDF, NDM, NDPR, NDRP, NPP and GY (Table 3) confirm the lack of adaptation of food type BRSMG 790A and BRS 257, as a result of earliness in number of days to first flower and number of days to maturity. BRS 257 was the earliest maturing cultivar flowering at $24 \mathrm{DAE}$ and finishing reproduction at $78 \mathrm{DAE}$. As a consequence it was the least yielding, $84 \%$ and $82 \%$ inferior to A7002 and M 8585, respectively. These results confirm the tests with BRS 257 in low latitude Formoso of Araguaia, TO (SANTOS et al., 2011b).

The food type BRSMG 790A had a total cycle of 96 days and did not differ statistically from A7002 for NDF. However, its reproductive period was 10 days inferior and this contributed to reduction in grain yield. Grain type cultivars yielded $2405 \mathrm{~kg} \mathrm{ha}^{-1}$ higher than BRSMG 790A. Moreover, the difference of 12 days in total plant cycle also impacted negatively plant height as BRSMG 790A was, on average, $41 \%$ less than A7002 and M 8585 (Figure 2A).

The growth analysis measurements as leaf area, leaf area index, leaf area ratio, net assimilation rate and relative growth ratio were efficient to demonstrate the lack of adaptation of BRSMG 790A and BRS 257 at latitude $11^{\circ} 43^{\prime}$ and lower. This was corroborated by the agronomic characteristics as number of days to flowering, number of days to reproduction, number of pods per plant and grain yield. 
Even though the BRSMG 790A and BRS 257 food type cultivars did not show adaptability to the low latitudes of Tocantins State, they could be useful in breeding programmes to cross with long juvenile trait genotypes as A7002 and M 8585. The genetics of both characters: long juvenile trait and lack of lypoxigenase are conditioned by few alleles (CARPENTIERI-PIPOLO et al., 2009; LENIS et al., 2010).

The possible recombinants should include both traits and food type adapted genotypes can be acquired, enlarging the possibilities of rationalizing soybean production to suit increasing food market demand.

\section{CONCLUSIONS}

Existing lipoxigenase-free, food type, soybean cultivars are not adapted to commercial cultivation at $11^{\circ} 43^{\prime}$ and lower latitudes of Tocantins State.

Food type cultivar BRS 257 matures in 78 days, presenting reduced plant height, number of pods per plant, and grain yield while BRS790A extends the plant cycle but its agronomic performance is still inferior to the common type, long juvenile phase A7002 and M 8585 cultivars.

Growth analysis is efficient to quantify the biological response of food type soybeans when grown at low latitudes.

Food type soybeans are useful in breeding programs aiming at acquisition of long-juvenile and lypoxygenase-free soybean genotypes.

\section{REFERENCES}

ALVAREZ, R.C.F.et al. Leaf gas exchange and yield of three upland rice cultivars. Bragantia, Campinas, v.74, n. 1, p.1-8, 2015. < http://dx.doi.org/10.1590/1678-4499.0322>.

ALMEIDA, L.A.et al. Melhoramento da soja para regiões de baixas latitudes. In: QUEIROZ, M.A.; GOEDERT, C.O.; RAMOS, S.R.R. (Eds.) Recursos genéticos e melhoramento de plantas para o nordeste brasileiro. Petrolina, EMBRAPA. 1999.

<http://www.alice.cnptia.embrapa.br/bitstream/doc/981323/1/LVsojamelhoramento.pdf>

BULEGON, L.G.et al. Crescimento e trocas gasosas no período vegetativo da soja inoculada com bactérias diazotróficas. Nativa, Sinop, v.4, n.5, p.277-286, 2016. <http://dx.doi.org/10.14583/23187670.v04n05a03>

CAMPOS, M.F.et al. Growth analysis of soybean plants treated with growth regulators. Biotemas, Florianópolis, v.21, p.53-63, 2008.

<https://periodicos.ufsc.br/index.php/biotemas/article/view/20738>.

CARPENTIERI-PIPOLO, V.et al. Inheritance of long juvenile period under short day conditions for the BR80-6778 soybean (Glycine max (L.) Merrill) line. Euphytica, v.112, p.203-209, 2000. http://link.springer.com/article/10.1023\%2FA\%3A1003927817278.

CRUZ, T.V.; PEIXOTO, C.P.; MARTINS, M.C. Growth and yield of soybean cultivar in sowing date function. Scientia Agraria, Curitiba, v.11, p.033-042, 2010. https://dialnet.unirioja.es/servlet/articulo?codigo $=3195990$.

FEHR, W.R.et al. Stage of development descriptions for soybeans, Glycyne max L. Merril. Crop Science, Madison, v.11, p.929-931, 1971. <DOI: 10.2135/cropsci1971.0011183X001100060051x>. 
FREITAS, R.M.O.et al. Cowpea growth as affected by dry spells in no-tillage and conventional systems. Bioscience Journal, Uberlandia, v.30, p.393-401, 2014.

<http://www.seer.ufu.br/index.php/biosciencejournal/article/view/17982/13754>.

HEIFFIG, L.S.et al. Closed canopy and leaf area index of soybean in different spatial arrangements. Bragantia, Campinas, v.65, p.285-295, 2006. <http://dx.doi.org/10.1590/S0006-87052006000200010>

HOFFMANN, W.A.; POORTER, H. Avoiding bias in calculation of relative growth rate. Annals of Botany, Oxford, v.91, p.685-689, 2002.

<http://aob.oxfordjournals.org/content/90/1/37.full.pdf+html>.

IUSS Working Group WRB. World Reference Base for Soil Resources 2014, update. International soil classification system for naming soils and creating legends for soil maps, World Soil Resources Reports No. 106. FAO, Rome, 2015.

KOTTEK, M.et al. World Map of the Köppen-Geiger climate classification updated. Meteorologische Zeitschrift, v.15, p.259-263, 2006.

〈http://koeppen-geiger.vu-wien.ac.at/pdf/Paper_2006.pdf〉.

LENIS, J.M.et al. Soybean seed lipoxygenase genes: molecular characterization and development of molecular marker assays. Theoretical and Applied Genetics, v.120, p.1139-1149, 2010.

<http://www.ncbi.nlm.nih.gov/pubmed/20058147>.

LUDWIG, Fet al. Growth analysis of potted gerbera grown in different substrates. Horticultura Brasileira, Brasília, v.28, p.70-74, 2010. <http://dx.doi.org/10.1590/S0102-05362010000100013>

MARTINAZZO, E.G.et al. Growth analysis and assimilate partitioning in tomato plants cv. Micro-Tom exposed to nitrogen and pyraclostrobin. Semina Ciências Agrárias, Londrina, v.36, p.3001-3012, 2015. <http://www.uel.br/revistas/uel/index.php/semagrarias/article/view/16813>.

MEHMET SINCIK, A.; GÖKSOY, T.; METIN TURAN, Z. How Growth Dynamics Affect Soybean Development across Cultural Practices, Soybean - Applications and Technology, Prof. Tzi-Bun Ng (Ed.), InTech, DOI: 10.5772/14290, 2011.

<http://www.intechopen.com/books/soybean-applications-andtechnology/how-growth-dynamics-affectsoybean-development-across-cultural-practices $>$

MORRISON, M.J.; VOLDENG, H.D.; COBER, E.R. Physiological Changes from 58 Years of Genetic Improvement of Short-Season Soybean Cultivars in Canada. Crop Science, Madison, v.91, p.685-689, 1999.

<https://dl.sciencesocieties.org/publications/aj/abstracts/91/4/685>.

NGUY-ROBERTSON, A.et al. Green Leaf Area Index Estimation in Maize and Soybean: Combining Vegetation Indices to Achieve Maximal Sensitivity. Agronomy Journal, Madison, v.10, p.1336-1347, 2012.

〈http://calmit.unl.edu/people/agitelson2/pdf/2012/aj-aj12-0065.pdf〉.

OLIVEIRA, P.; NASCENTE, A.S.; KLUTHCOUSKI, J. Soybean growth and yield under cover crops.

Revista Ceres, Viçosa, v.60, p.249-256, 2013.

<http://dx.doi.org/10.1590/S0034-737X2013000200014>.

PAPA, R.A. Spectro flaw-behavior of bean crop based on data obtained by spectrometer, digital camera and ASTER image. 2009. 132p. M.Sc. Thesis. Faculty of Agronomy and Veterinary Medicine, Universidade de Brasília, 2010.

PEDERSEN, P.; LAUER, J.G. Soybean growth and development in various management systems and planting dates. Crop Science, Madison, v.44, p.508-515, 2004.

$<$ http://citeseerx.ist.psu.edu/viewdoc/download?doi=10.1.1.580.6126\&rep=rep1\&type=pd> 
PRICE, C.; MUNNS, R. Growth analysis: a quantitative approach. In: Munns R, Schmidt S \& Beveridge C (Eds.) Plants in action. Australian Society of Plant Scientists, New Zealand Society of Plant Biologists, and New Zealand Institute of Agricultural and Horticultural Science, 2010.

$\langle$ http://plantsinaction.science.uq.edu.au/content/about>.

SANTOS, E.R.et al. Growth and rates of leaf pigment in cowpea beans grown in two light environments. Revista Caatinga,Mossoro, v.24, p.14-19, 2011 a.

<http://periodicos.ufersa.edu.br/revistas/index.php/sistema/article/viewFile/1619/pdf>

SANTOS, E.R.et al. Divergence between soybean genotypes grown in irrigated low land, Brazil. Revista Ceres, Viçosa, v.58, p.755-764, $2011 \mathrm{~b}$.

<http://www.scielo.br/scielo.php?script=sci_arttext\&pid=S0034-737X2011000600012>.

SANTOS, V.M.et al. Avaliação do crescimento e da produtividade da mamoneira BRS 149, Nordestina em dois níveis tecnológicos. Journal of Biotecnology and Biodiversity, Gurupi, v.2, p.58-66, 2011c. $<$ http://revista.uft.edu.br/index.php/JBB/article/view/250>

SILVA, J.B.et al. Isoflavone contents of whole soybeans and their components, obtained from different cultivars (Glycine max (L.) Merrill). Brazilian Journal of Food Technology, Campinas, v.15, p.150-156, 2012. <http://dx.doi.org/10.1590/S1981-67232012005000008>.

SILVA, J.B.; CARRÃO-PANIZZI, M.C.; PRUDÊNCIO, S.H. Chemical and physical composition of grain-type and food-type soybean for food processing. Pesquisa Agropecuária Brasileira, Brasília, v.44, p.777-784, 2009.

<http://www.scielo.br/scielo.php?script=sci_arttext\&pid=S0100-204X2009000700019\&lng=en>

SOUZA, A.J.J.et al. Quantitative analysis of growth in coffee plants cultivated with a water-retaining polymer in an irrigated system. Revista Ciência Agronômica, Fortaleza, v.47, p.162-171, 2016. <http://ccarevista.ufc.br/seer/index.php/ccarevista/article/view/3726/1307〉.

SPEHAR, C.R; FRANCISCO, E.R; PEREIRA, E.A. Yield stability of soybean cultivars in crop seasons and sowing dates at low latitude Brazilian Savannah Highlands. Journal of Agricultural Science, Cambridge, v.153, p.1059-1068, 2014.

<http://dx. doi.org/10.1017/s0021859614000781>.

YUSUF, I.R.; SIEMENS, J.C.; BULLOCK, D.G. Growth analysis of soybean under no-tillage and conventional tillage systems. Crop Science, Madison, v.91, p.928-933, 1999.

<https://dl.sciencesocieties.org/publications/aj/abstracts/91/6/928>. 